\title{
Genome-Wide Association Study in Wheat Identifies Resistance to the Cereal Cyst Nematode Heterodera filipjevi
}

\author{
Shree R. Pariyar, Abdelfattah A. Dababat, Wiebke Sannemann, Gul Erginbas-Orakci, Abdelnaser Elashry, Shahid Siddique, \\ Alexei Morgounov, Jens Leon, and Florian M. W. Grundler
}

First, fifth, sixth, and ninth authors: Institute of Crop Science and Resource Conservation (INRES), Molecular Phytomedicine, KarlrobertKreiten Strasse 13, D-53115 Bonn, Germany; second, fourth, and seventh authors: International Maize and Wheat Improvement Centre (CIMMYT), P.K. 39 06511, Emek, Ankara, Turkey; third and eighth authors: Institute of Crop Science and Resource Conservation (INRES), Plant Breeding, Katzenburgweg; and fifth author: Agricultural Research Center (ARC), Agricultural genetic Engineering Research Institute (AGERI), 9 Gama Street, Giza 12619, Egypt.

Current address of third author: University Halle-Wittenberg, Plant Breeding, Betty-Heimann-Strasse 3, 06120 Halle (Saale).

Accepted for publication 10 June 2016.

\begin{abstract}
Pariyar, S. R., Dababat, A. A., Sannemann, W., Erginbas-Orakci, G., Elashry, A., Siddique, S., Morgounov, A., Leon, J., and Grundler, F. M. W. 2016. Genome-wide association study in wheat identifies resistance to the cereal cyst nematode Heterodera filipjevi. Phytopathology 106:1128-1138.

The cyst nematode Heterodera filipjevi is a plant parasite causing substantial yield loss in wheat. Resistant cultivars are the preferred method of controlling cyst nematodes. Association mapping is a powerful approach to detect associations between phenotypic variation and genetic polymorphisms; in this way favorable traits such as resistance to pathogens can be located. Therefore, a genome-wide association study of 161 winter wheat accessions was performed with a $90 \mathrm{~K}$ iSelect single

nucleotide polymorphism (SNP) chip. Population structure analysis grouped into two major subgroups and first principal component accounted $6.16 \%$ for phenotypic diversity. The genome-wide linkage disequilibrium across wheat was $3 \mathrm{cM}$. Eleven quantitative trait loci (QTLs) on chromosomes $1 \mathrm{AL}, 2 \mathrm{AS}, 2 \mathrm{BL}, 3 \mathrm{AL}, 3 \mathrm{BL}, 4 \mathrm{AS}, 4 \mathrm{AL}, 5 \mathrm{BL}$, and 7BL were identified using a mixed linear model false discovery rate of $P<$ 0.01 that explained $43 \%$ of total genetic variation. This is the first report of QTLs conferring resistance to $H$. filipjevi in wheat. Eight QTLs on chromosomes 1AL, 2AS, 2BL, 3AL, 4AL, and 5BL were linked to putative genes known to be involved in plant-pathogen interactions. Two other QTLs on 3BL and one QTL on 7BL linked to putative genes known to be involved in abiotic stress.
\end{abstract}

Bread wheat (Triticum aestivum L.) is a major staple food for the world's population. It was one of the first domesticated cereals composed of three closely related and independently maintained genomes. The hexaploid genome (AABBDD) was formed by multiple hybridization events among the three different progenitor species. The ancestral progenitor genomes of Triticum urartu (AA) and most probably Aegilops speltoides (BB) hybridized to produce tetraploid emmer wheat Triticum turgidum ssp. dicoccoides (AABB, $2 \mathrm{n}=28$ ), which again hybridized with goat grass A. tauschii (DD, $2 \mathrm{n}=14)$ to produce modern bread wheat (Huang et al. 2002). Bread wheat production is limited by many biotic and abiotic factors, especially in rain-fed regions (Dababat et al. 2015). Cereal cyst nematodes (CCN) are an important group of plantparasitic nematodes attacking cereals. $\mathrm{CCN}$ consist of several closely related nematode species such as Heterodera avenae, $H$. latipons, $H$. filipjevi, $H$. hordecalis, $H$. zeae, $H$. mani, $H$. bifenestra, $H$. pakistanensis, $H$. arenaria, and $H$. pratensis are referred as $\mathrm{CCN}$ complex (Nicol and Rivoal 2008). H. filipjevi, H. avenae, and H. latipons are the three important Heterodera spp. reported to cause economic losses in small grain crops (Rivoal and Cook 1993). $H$. avenae is reported from all over the continents, while $H$. latipons is reported from Asia, Europe, Africa, and North America (Scholz and Sikora 2004; Sikora 1988). H. filipjevi is one of the most damaging

Corresponding author: F. M. W. Grundler; E-mail address: grundler@uni-bonn.de

*The $\boldsymbol{e}$-Xtra logo stands for "electronic extra" and indicates that two supplementary figures and two supplementary tables are published online.

http://dx.doi.org/10.1094/PHYTO-02-16-0054-FI

(C) 2016 The American Phytopathological Society species with yield losses that locally may reach $50 \%$ (Rivoal and Nicol 2009).

Cyst nematodes of the genus Heterodera are biotrophic sedentary endoparasites that rely on the formation of specific hypertrophic and hypermetabolic nurse cell system (syncytium) close to the vasculature of the root. For development and reproduction, a female has to feed from a single syncytium for several weeks (Hussey and Grundler 1998). Nematode resistance in plants is characterized by limiting or preventing female development (Williamson and Kumar 2006), so the nematode population density eventually is decreased. Reduced female development may be caused by diminished nematode attraction, pronounced formation of structural barriers, increase of defense responses to nematode invasion, and failure or limitation of feeding site formation and therefore nematode development. Wheat landraces and domesticated accessions possess genetic variation including resistance to biotic and abiotic stresses (Kimber and Feldman 1987). Resistance sources to CCN include germplasm of A. tauschii (Coss.) (syn. Triticum tauschii (Coss.) Schmal; syn. A. squarrosa auct. non L.) and T. turgidum ssp. dicoccoides (Loureiro et al. 2009; McDonald et al. 2005; Nicol and Rivoal 2008; Rivoal et al. 2001; van Slageren 1994). Resistance to $H$. avenae was described in barley and in bread wheat (Holm Nielsen 1966; Nilsox-Ehle 1920). Nine single dominant genes known as Cre were found in wild relatives of wheat and successfully used to manage $H$. avenae, e.g., in Australia, France, India and Sweden (Ogbonnaya et al. 2009).

Host resistance is preferred to manage nematodes in wheat since it is effective and safe (McIntosh 1997). However, only a few resistance genes to $\mathrm{CCN}$ have been genetically mapped in wheat (Mokabli et al. 2002; Rivoal et al. 2001). Understanding the genetic background through mapping traits provides a baseline for breeding and gene cloning. Historically, quantitative trait loci (QTL) detection started 
with linkage mapping in biparental populations to exploit unadapted germplasm (Würschum 2012). However, the detection of closely linked markers in parental populations are limited by relatively few recombination events in linkage mapping (Riedelsheimer et al. 2012). Association mapping (AM) is an approach based on linkage disequilibrium (LD) between molecular markers and functional loci. Its high resolution makes it possible to detect historical recombinations in accumulated natural populations, landraces, breeding materials and varieties (Soto-Cerda and Cloutier 2012). Phenotype and genotype of a large set of unrelated accessions are determined and correlated to identify the alleles at gene regions (Flint-Garcia et al. 2003; Rafalski 2002). AM was used to identify QTLs and characterize candidate genes in several crops, such as rice, maize, barley, and wheat (Agrama et al. 2007; Cockram et al. 2010; Kump et al. 2011; Massman et al. 2011; Mulki et al. 2013; Neumann et al. 2011; Tommasini et al. 2007; Wang et al. 2001; William et al. 2003; Zou et al. 2000). Molecular markers such as restriction fragment length polymorphism, amplified fragment length polymorphisms, simple sequence repeats, diversity arrays technology or genomespecific sequence tagged sites were utilized in wheat for identifying QTLs, including yield, grain quality (Tadesse et al. 2015), and resistance to Stagonospora nodorum blotch (Tommasini et al. 2007; Yao et al. 2009) and H. avenae (Mulki et al. 2013). However, an uneven distribution and low reproducibility across the wheat genome has limited the application of these markers. The availability of a dense single nucleotide polymorphism (SNP) marker chip allows an efficient detection of target genes to uncover multiple targets in wheat because of its wide distribution in genomes and adaptation to high multiplex detection systems (Akhunov et al. 2009; Wang et al. 2014; $\mathrm{Xu}$ and Crouch 2008). As we tested wheat accessions for resistance to $H$. filipjevi and found differences in the resistance response, we hypothesized that the relevant genes/QTLs can be detected by association mapping. Therefore, the main objective of this study was to investigate the QTLs/genes conferring resistance to $H$. filipjevi in 161 diverse winter wheat accessions using genome-wide association study (GWAS).

\section{MATERIALS AND METHODS}

Wheat accessions screening assay. One hundred sixty-one winter wheat accessions (101 breeding lines, 58 cultivars, and 2 landraces) from the International Winter Wheat Improvement Program (IWWIP) were tested for CCN H. filipjevi levels (Supplementary Table S1). The accessions were selected based on diverse genetic background. Seven seeds from each spike were germinated on moistened tissue placed in Petri dishes for 3 days at $22^{\circ} \mathrm{C}$. After germination, five seedlings of similar size and development were selected. A sterilized potting mixture of sand, field soil and organic matter (70:29:1, vol/vol/vol) was filled in RLC4-pine tubes $(25 \mathrm{~mm}$ in diameter by $160 \mathrm{~mm}$ in height, Ray Leach Cone-tainer, Stuewe \& Sons, Inc.). Each plant was inoculated with 250 freshly hatched $\mathrm{J} 2 \mathrm{~s}$ of $H$. filipjevi 7 days after transplanting and set in completely randomized design. The nematode inoculum used in these experiments was obtained from a pure culture (Pariyar et al. 2016). Plants were grown at $23 \pm 2{ }^{\circ} \mathrm{C}, 16 \mathrm{~h}$ of artificial light and $65 \%$ relative humidity. Twenty-five days after planting, plants were fertilized with water-soluble Nitrophoska Solub/Hakaphos (20:19:19 NPK including micro-elements such as $\mathrm{P}_{2} \mathrm{O}_{5}, \mathrm{~K}_{2} \mathrm{O}, \mathrm{B}, \mathrm{Cu}, \mathrm{Fe}, \mathrm{Mn}, \mathrm{Mo}$, and $\mathrm{Zn}, \mathrm{COMPO} \mathrm{GmbH}$ and $\mathrm{Co}$. $\mathrm{KG}$, Germany) at $1 \mathrm{~g}$ liter $^{-1}$ of tap water. Plants were harvested at 63 days postinfection and cyst from both the soil and the roots were extracted. The soil from each tube was poured into a 2-liter beaker filled with water and the soil mixture was stirred, and then left for about $30 \mathrm{~s}$ to allow the heavy sand and soil debris to settle down. Roots were washed very gently on the upper sieve to free any females and cysts left attached to the root system. The soil mixture was poured through 850 and $250 \mu \mathrm{m}$ sieves. This process was repeated three times to ensure all females and cysts were successfully collected. Females and cysts from both roots and soil were captured on the $250 \mu \mathrm{m}$ sieve and counted under a dissecting microscope. The roots were further checked for females and cysts that had not been dislodged during the washing process. The response of the tested wheat accessions was determined and categorized into five groups based on mean number of females and cysts recorded per plant. The experiment was repeated twice. The following ranking was used: resistant $(\mathrm{R})=<5$ females and cysts/ plant; moderately resistant $(\mathrm{MR})=5$ to 10 females and cysts/plant; moderately susceptible (MS) = 11 to 15 females and cysts/plant; susceptible $(\mathrm{S})=16$ to 19 females and cysts/plant; and highly susceptible $(\mathrm{HS})=>20$ females and cysts/plants (Pariyar et al. 2016). The widely grown winter wheat cultivar Bezostaya 1 in Turkey was used as the susceptible control. The phenotypic data were analyzed using a mixed linear model implemented in Proc mixed procedure in SAS 9.2. Variance components were estimated according to the following model:

$Y_{i j k}=\mu+$ year $_{i}+\operatorname{block}_{k}\left(\right.$ year $\left._{i}\right)+$ accession $_{j}+\operatorname{accession}_{j}$ by year $_{i}+\varepsilon_{i j k}$

where $Y_{i j}$ is response variable, $\mu$ is overall mean, year is the random effect of year, accessions ${ }_{j}$ is the fixed effect of the accession, block $_{k}$ is the random effect of the block with year, and $\varepsilon_{i j k}$ is the random error. The data were analyzed by restricted maximum likelihood to fit a mixed model. To analyze total genetic variance to total phenotypic variance, heritability $\left(H^{2}\right)$ was estimated by using PROC VARCOMP in SAS 9.2 (SAS Institute Inc., Cary, NC). Broad-sense heritability was calculated using $H^{2}=\sigma^{2}{ }_{g} /\left(\sigma^{2}{ }_{g}+\sigma^{2}{ }_{e} / n\right)$, where $\sigma^{2}{ }_{g}$ is the genotypic variance, $\sigma^{2}{ }_{e}$ is the environment variance, and $n$ is the number of environments (Holland et al. 2003).

SNP Genotyping and molecular data. Genomic DNA was isolated from 7-day-old wheat seedling leaf tissue using the cetyl trimethyl ammonium bromide (CTAB) method (Sharp et al. 1988). The quality of DNA was evaluated on a $0.8 \%$ agarose gel and normalized to $50 \mathrm{ng} / \mu \mathrm{l}$. A DNA aliquot of $2 \mu \mathrm{l}$ from each sample was used for genotyping by $90 \mathrm{~K}$ Illumina iSelect Wheat Bead Chip, TraitGenetics GmbH, Gatersleben, Germany. To avoid monomorphic and low-quality SNPs, data were analyzed by Genome Studio software and transcribed into binary matrix software (Cavanagh et al. 2013). We defined minor allele (less frequent) as zero, major allele (more frequent) as one, and heterozygous scores as missing data. All monomorphic markers, the number of missing data greater than $5 \%$ and SNP markers with a minor allele frequency (MAF) less than 5\% were removed to reduce false positive QTLs (Myles et al. 2009).

Linkage disequilibrium. Pair-wise measures of LD were performed to analyze the squared correlation coefficient $\left(r^{2}\right)$ between two loci and summarize both mutational and recombination history. The extent of LD across the wheat genome was estimated by 11,680 markers with known chromosomal positions based on the International Triticeae Mapping Initiative map using a SAS 9.2 (Cavanagh et al. 2013). The values were plotted for each linkage group by genetic distance using a SAS/LD heatmap (Breseghello and Sorrells 2006). The LD decay to 0.1 was considered as the critical distance up to which a QTL region extends. LD heat maps for significant markers were created by using Haploview software (Barrett et al. 2005).

Population structure and kinship. Genetic subpopulations were analyzed using a model-based Bayesian clustering method implemented software STRUCTURE 2.3.4 with 961 polymorphic markers. The 961 markers were selected based on their 5 centimorgan (cM) grid distances from the total 11,680 markers with known chromosomal positions. Twenty independent runs were performed setting the hypothetical number of expected populations $(\mathrm{K})$ range from 1 to 20 . The data were processed by an admixture model using a burn-in period of 10,000 and run length of 100,000 (Evanno et al. 2005). K value was determined by estimated normal logarithm of the probability of fit (LnP(D)) provided in the STRUCTURE output and an ad hoc statistic $\triangle K$ based on the rate of change in $L n P(D)$ between successive K values (Earl 2012). The estimated log probability 
LnP(D) increased continuously with increasing $\mathrm{K}$ and $\triangle \mathrm{K}$, and was plotted against the number of subpopulations K (Evanno et al. 2005). Results were analyzed to interpret the origin and geographic distribution of the populations. Further, the principal components (PC) were estimated using the Princomp procedure in SAS 9.2 to clarify the population structure in the populations (Price et al. 2006). Principal component analysis (PCA) was analyzed by TASSEL v.3.0 (http://www.maizegenetics.net) with a total of 22,364 polymorphic SNP markers using as covariance matrix and analyzed for GWAS (Bradbury et al. 2007). The data were further analyzed by (P matrix and $\mathrm{P}+\mathrm{K})$ (Price et al. 2006). PCs were treated as fixed effects and kinship (K matrix) was used to analyze the variance and covariance structure of random individual effects (Yu and Buckler 2006).
Marker-trait associations. To identify significant QTLs conferring resistance to $H$. filipjevi, a multiple QTL model that corrected for both population structure and familial relatedness was developed using a mixed linear model (MLM) approach (promixed, SAS 9.2) (Bauer et al. 2009). The phenotypic variation $\left(R^{2}\right)$ was calculated using a simple regression equation implemented in the program. Association between SNPs and nematode resistance was considered significant at $P \leq 0.01$ (Malosetti et al. 2007). The threshold LOD scores were calculated using 1,000 permutations. The least squares means of significant marker alleles were estimated and a stepwise regression forward/backward diministic process SAS promixed procedure was used to estimate the combined variation explained by the markers. A single-locus analysis was conducted and

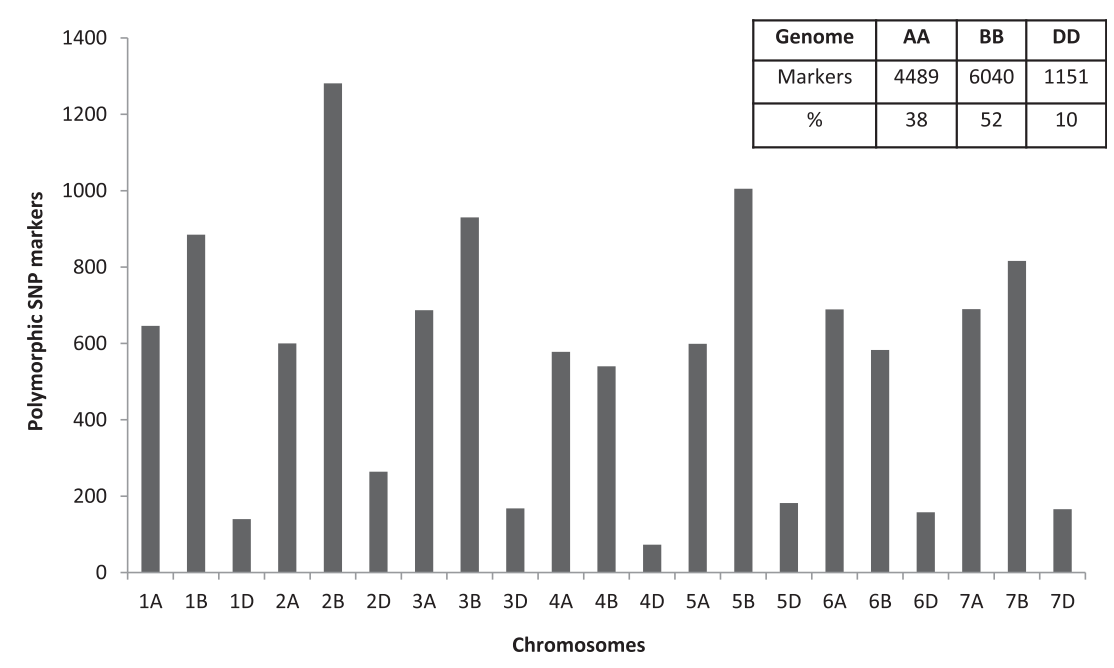

Fig. 1. Distribution of single nucleotide polymorphism (SNP) markers across wheat chromosomes.
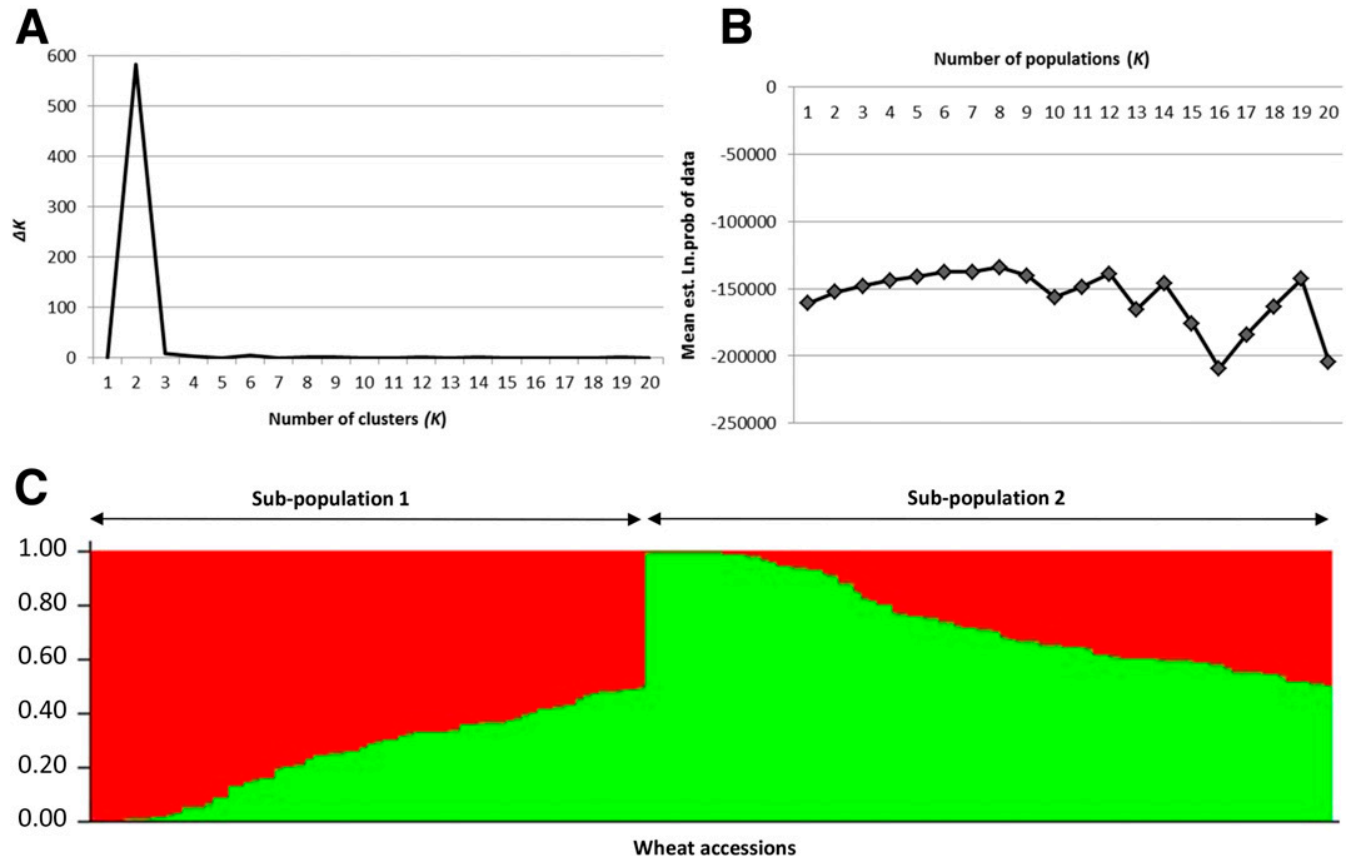

Fig. 2. Estimation of number of subpopulations (K) in winter wheat based on 961 single nucleotide polymorphism (SNP) markers. A, Estimation of number of subpopulations $(\mathrm{K})$ in winter wheat using $\Delta \mathrm{K}$ values. B, The log probability of data as a function of $\mathrm{K}$ for $961 \mathrm{SNP}$ markers. Means log probability of data $\mathrm{LnP}(\mathrm{D})$ for each value of $\mathrm{K}$ were calculated from 20 independent runs of structure. C, Two subgroups inferred from STRUCTURE analysis. The vertical coordinate of each subgroup indicates the membership coefficients for each individual represented by a colored line where each color reflects the cultivar in one of the $\mathrm{K}$ clusters. The proportion of the colored segment red and green indicates the proportion of the genome drawn from the K clusters and represents the geographic eco-type information of wheat accessions. 
the most significant marker based on $P$ value was chosen as fixed cofactor in the model. In addition, a multilocus analysis with cross validation was used to reduce false discovery rate of QTL by controlling FDR at $P \leq 0.05$ (Bauer et al. 2009; Benjamini and Yekutieli 2005).

Functional annotation of putative genes linked to SNP marker associated to $\mathbf{C C N}$ resistance. To analyze the putative biological functions of genes associated to $\mathrm{CCN}$ resistance, we performed an in-silico functional annotation of significant SNP markers. The flanking sequences of the significant SNP markers were blasted against gene models of Brachypodium distachyon, Oryza sativa, and Sorghum bicolor available in the International wheat genome sequencing consortium (IWGSC), the Institute for Genomic Research (TIGR) Wheat genome annotation, and National Center for Biotechnology Information (NCBI). The genes/proteins were selected based on significant hit and lowest expected (e)-value, and putative functions were analyzed. To identify the full open reading frame $(\mathrm{ORF})$ at significant marker locations, we downloaded the available wheat transcriptome assemblies from the MAS Wheat dataset (Krasileva et al. 2013). All datasets were imported in the CLC genomic workbench and blast database sequences lower than e-value 0.0e-15 were considered positive. Further, the putative genes were blasted in The Arabidopsis Information Resource (TAIR), and similar predicted proteins/genes homologs were described as annotated functions. If the significant marker was in a coding region, the substitution was designated as synonymous (no change in amino acid) or nonsynonymous substitution (change in amino acid).

\section{RESULTS}

Wheat accessions screening assay. Screening of 161 modern winter wheat accessions revealed variability in response to nematode infection. The results revealed $1 \%$ of the studied wheat accessions to be resistant, $26 \%$ moderately resistant, $26 \%$ moderately susceptible, $22 \%$ susceptible, and $24 \%$ highly susceptible to $H$. filipjevi.

Density of polymorphic SNP markers differs between the A, B, and D genomes. 23,364 polymorphic SNPs were obtained after removing all monomorphic markers, markers with a MAF $<5 \%$ and missing data $>5 \%$. Fifty percent $(11,680)$ of SNPs with known chromosomal locations were recorded and used for LD analysis. A total genomic size of $2956.5 \mathrm{cM}$ was measured with the 11,680 markers across 21 chromosomes of the 161 wheat accessions (Fig. 1). The results

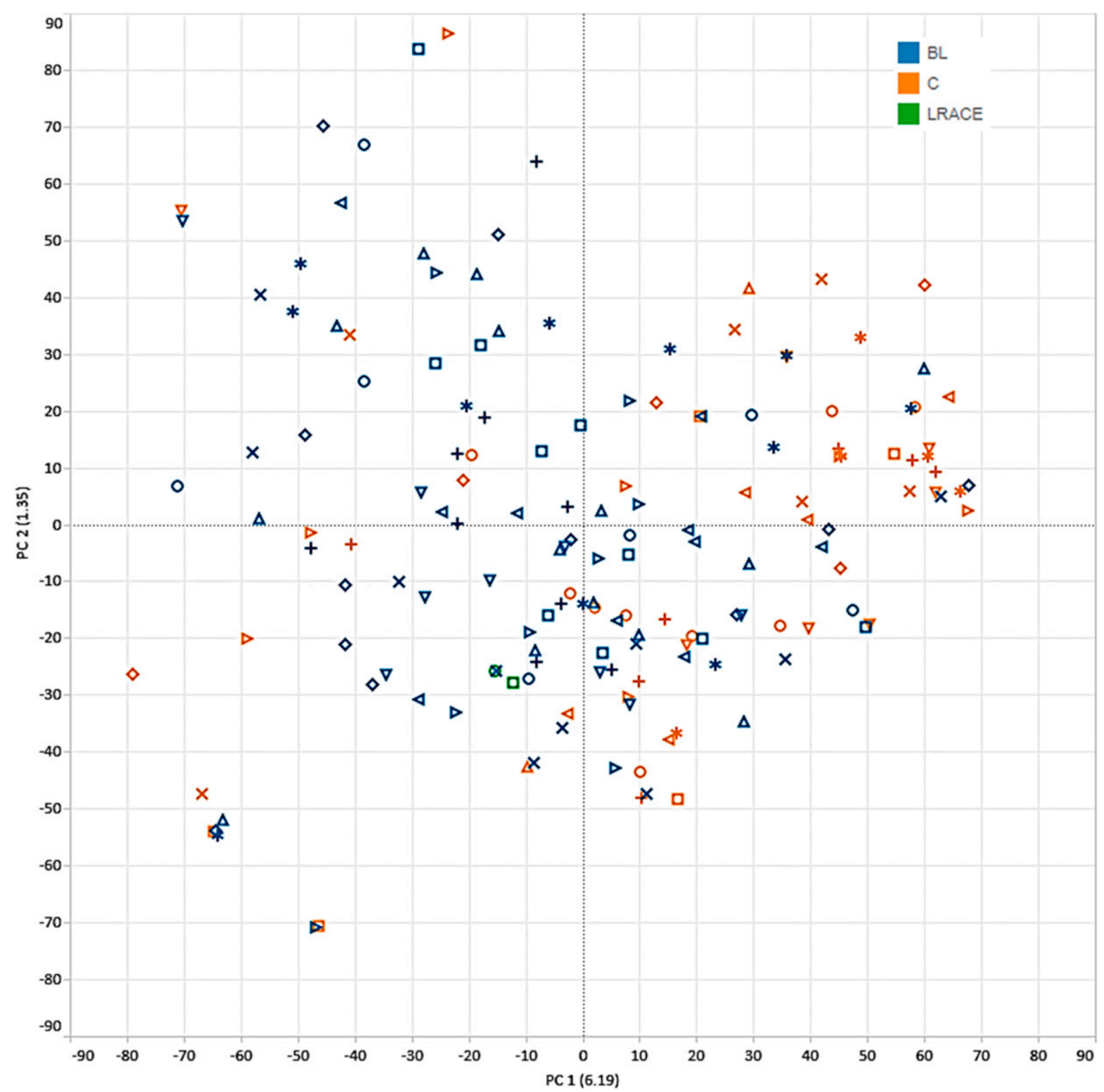

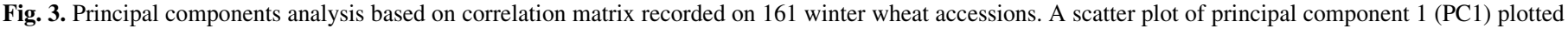
against principal component 2 (PC2). Each symbol represents a wheat accession in mapping panel. BL = breeding line; C = cultivar, LRACE = landrace. 
showed an uneven distribution of mapped markers across wheat genomes A, B, and D. A high density of SNPs was located on genomes A $(38.43 \%)$ and B $(51.71 \%)$, while a relatively low number of SNPs were detected on genome D $(9.85 \%)$. The highest number of polymorphic markers was located on chromosome $2 \mathrm{~B}(1,281$ SNPs, $11 \%$ ) with a SNP marker each $0.11 \mathrm{cM}$ on average. The lowest number of polymorphic markers was distributed on chromosome 4D (73 SNPs, $0.63 \%$ ) with a SNP marker each $1.55 \mathrm{cM}$. On average, one marker was mapped each $0.25 \mathrm{cM}$ over all chromosomes.

Population structure and kinship. The ad hoc quantity based on the second order rate of change in the log probability $(\Delta \mathrm{K})$ showed a clear peak at $\mathrm{K}=2$ (Fig. 2A), indicating two genetic subpopulations. The logarithm of the data likelihood (LnP(D)) on average continued to increase with increasing numbers of assumed subpopulations $(\mathrm{K})$ from 2 to 20 with exception of the depression at K10, K13 and K16 (Fig. 2B). The first group consisted of 89 winter wheat accessions mostly originating from South Africa (5), and Iran (2), including the United States (1), whereas the second group was composed of 72 wheat accessions mainly originated from Russia (8), Bulgaria (2), Moldova (2), including Turkey-CIMMYT ICARDA (3) (Fig. 2C). Population structure was further analyzed by conventional $F$-statistic $(F s t)$ analysis. The average fixation index between subpopulations

TABLE 1. A genetic linkage map, single nucleotide polymorphism (SNP) marker, and linkage disequilibrium decay in wheat 161 wheat accessions ${ }^{\mathrm{a}}$

\begin{tabular}{|c|c|c|c|c|c|}
\hline Chromosome & Number of SNP & SNP \% & Length (cM) & $\mathrm{cM} / \mathrm{SNP}$ & LD decay $r^{2} /(\mathrm{cM})$ \\
\hline $1 \mathrm{~A}$ & 646 & 5.53 & 111.7 & 0.17 & 4 \\
\hline $2 \mathrm{~A}$ & 600 & 5.14 & 120.5 & 0.20 & 1 \\
\hline $3 \mathrm{~A}$ & 687 & 5.88 & 169.6 & 0.25 & 2 \\
\hline $4 \mathrm{~A}$ & 578 & 4.95 & 161.8 & 0.28 & 4 \\
\hline $5 \mathrm{~A}$ & 599 & 5.13 & 117.7 & 0.20 & 2 \\
\hline $6 \mathrm{~A}$ & 689 & 5.90 & 122.2 & 0.18 & 3 \\
\hline $7 \mathrm{~A}$ & 690 & 5.91 & 167.5 & 0.24 & 1 \\
\hline $1 \mathrm{~B}$ & 885 & 7.58 & 117.7 & 0.13 & 1 \\
\hline $2 B$ & 1,281 & 10.97 & 145.0 & 0.11 & 2 \\
\hline $3 B$ & 930 & 7.96 & 137.0 & 0.15 & 2 \\
\hline $4 \mathrm{~B}$ & 540 & 4.62 & 107.0 & 0.20 & 2 \\
\hline $5 B$ & 1,005 & 8.60 & 179.0 & 0.18 & 3 \\
\hline $6 B$ & 583 & 4.99 & 110.4 & 0.19 & 2 \\
\hline $7 \mathrm{~B}$ & 816 & 6.99 & 142.0 & 0.17 & 2 \\
\hline 1D & 140 & 1.20 & 143.6 & 1.03 & 10 \\
\hline $2 \mathrm{D}$ & 264 & 2.26 & 141.6 & 0.54 & 2 \\
\hline $3 \mathrm{D}$ & 168 & 1.44 & 164.1 & 0.98 & 6 \\
\hline 4D & 73 & 0.63 & 112.9 & 1.55 & 4 \\
\hline $5 \mathrm{D}$ & 182 & 1.56 & 167.8 & 0.92 & 2 \\
\hline $6 \mathrm{D}$ & 158 & 1.35 & 122.3 & 0.77 & 2 \\
\hline $7 \mathrm{D}$ & 166 & 1.42 & 195.1 & 1.18 & 4 \\
\hline Total & 11,680 & 100 & $2,956.5$ & 0.25 & 2.9 \\
\hline
\end{tabular}

a cM, centimorgan; LD, linkage disequilibrium; and $r^{2}$, pair-wise measures of LD.

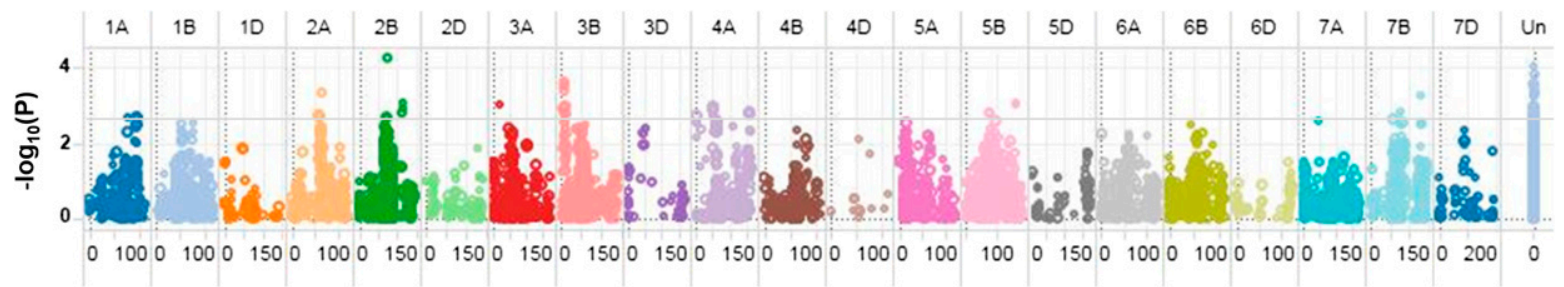

Distance cM

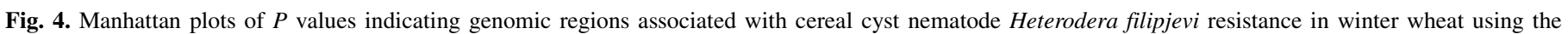
mixed linear model (MLM) $(\mathrm{P}+\mathrm{K}) . x$ axis shows single nucleotide polymorphism markers along each wheat chromosome; $y$ axis is the $-\log _{10}(P$ value).

TABLE 2. Significant markers associated with QTLs conferring resistance to Heterodera filipjevi in 161 winter wheat accessions ${ }^{\mathrm{a}}$

\begin{tabular}{|c|c|c|c|c|c|c|c|c|c|c|}
\hline $\mathrm{SN}$ & Marker & $\mathrm{CHR}$ & POS (cM) & Genetic interval & P-LOD & P-FDR & $P$ value & Allele & Allelic effect & $R^{2}(\%)$ \\
\hline 1 & wsnp_BE443588A_Ta_2_1 & $1 \mathrm{AL}$ & 97.10 & $94.0-97.1$ & 4.24 & 0.00055 & 0.00092 & $\mathrm{~A} / \mathrm{C}$ & -4.30 & 10.29 \\
\hline 2 & RAC875_c13116_943 & 2AS & 64.30 & 64.30 & 3.35 & 0.00164 & 0.00045 & $\mathrm{~A} / \mathrm{C}$ & -3.04 & 8.50 \\
\hline 3 & Excalibur_c18966_804 & $2 \mathrm{BL}$ & 113.60 & 113.60 & 2.91 & 0.00164 & 0.00122 & $\mathrm{G} / \mathrm{A}$ & -2.80 & 6.90 \\
\hline 4 & wsnp_BE4̄26418A_Ta_2_1 & $3 \mathrm{AL}$ & 20.00 & $20.0-26.4$ & 3.01 & 0.00164 & 0.00096 & $\mathrm{~T} / \mathrm{C}$ & -4.36 & 8.00 \\
\hline 5 & Bobwhite_rep_c66630_331 & 7BL & 79.10 & $68.6-79.1$ & 2.81 & 0.00164 & 0.00154 & $\mathrm{~T} / \mathrm{C}$ & -3.31 & 7.50 \\
\hline 6 & Tdurum_contig10380_87 & $2 \mathrm{BL}$ & 74.90 & 74.90 & 4.26 & 0.00056 & 0.00006 & $\mathrm{G} / \mathrm{A}$ & 4.36 & 12.10 \\
\hline 7 & Tdurum_contig12008_803 & $3 \mathrm{BL}$ & 6.14 & $0.0-6.14$ & 3.61 & 0.00024 & 0.00025 & $\mathrm{~T} / \mathrm{C}$ & 3.11 & 8.90 \\
\hline 8 & Excalibur_c20277_483 & 3BL & 6.14 & $0.0-6.15$ & 3.64 & 0.00164 & 0.00100 & $\mathrm{G} / \mathrm{A}$ & 3.40 & 7.40 \\
\hline 9 & wsnp_Ex_c55245_57821389 & $4 \mathrm{AS}$ & 53.30 & 53.30 & 2.98 & 0.00164 & 0.00104 & $\mathrm{~T} / \mathrm{C}$ & 2.77 & 7.50 \\
\hline 10 & Tdurum_contig82236_117 & $4 \mathrm{AL}$ & 155.50 & 155.50 & 2.82 & 0.00164 & 0.00152 & $\mathrm{G} / \mathrm{A}$ & 3.35 & 7.60 \\
\hline 11 & Excalibur_c78724_434 & $5 B L$ & 158.70 & 158.70 & 3.06 & 0.00164 & 0.00087 & $\mathrm{G} / \mathrm{A}$ & 3.65 & 8.10 \\
\hline
\end{tabular}

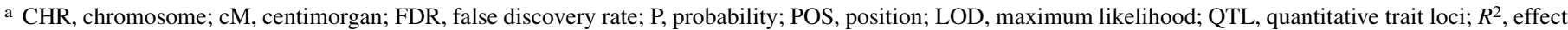
due to genetic variation; and SNP, single nucleotide polymorphism. 
ranged from 0.011 and 0.155 , while mean $0.034 F$ st revealed a very low population differentiation due to genetic structure. In addition, PCA was used to visualize the genotyping data (Fig. 3). The first, second, and third principal components explained 6.19, 1.35, and $1.0 \%$ of the variation, respectively. The low genetic variation exhibited by first PC $(6.19 \%)$ indicated no significant principal components in the mapping population (Franklin et al. 1995).
Linkage disequilibrium. The analysis of LD decay with 11,680 markers showed that the genome-wide LD across wheat was $3 \mathrm{cM}$ (Table 1). The $r^{2}$ values were plotted against the genetic distance. Beyond 3cM, LD became constant at a value of $r^{2}=0.1$, which allowed a precise genetic analysis. The low intrachromosomal linkages of all chromosomes were calculated (Table 1; Supplementary Fig. S1). The lowest LD decay was observed in chromosome 1D at
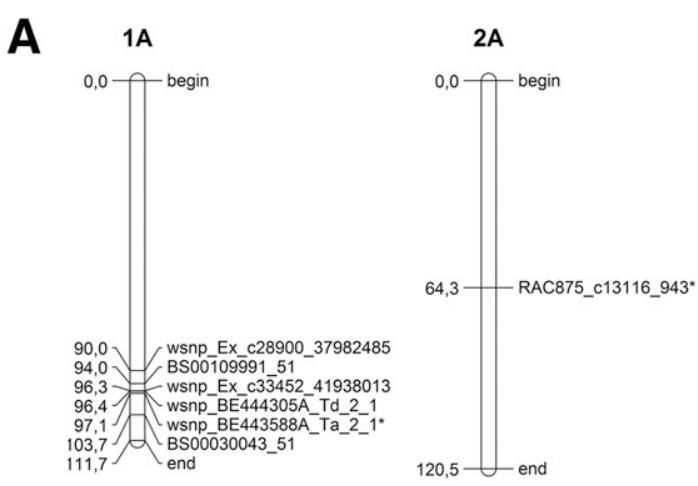

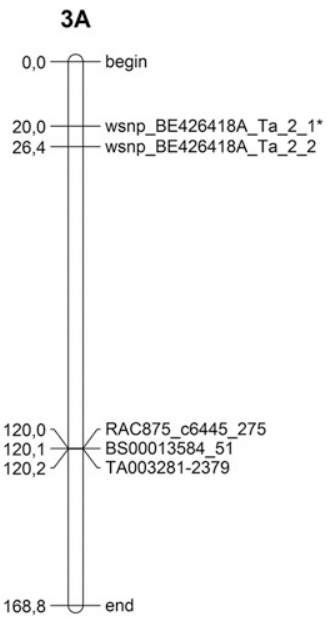

B
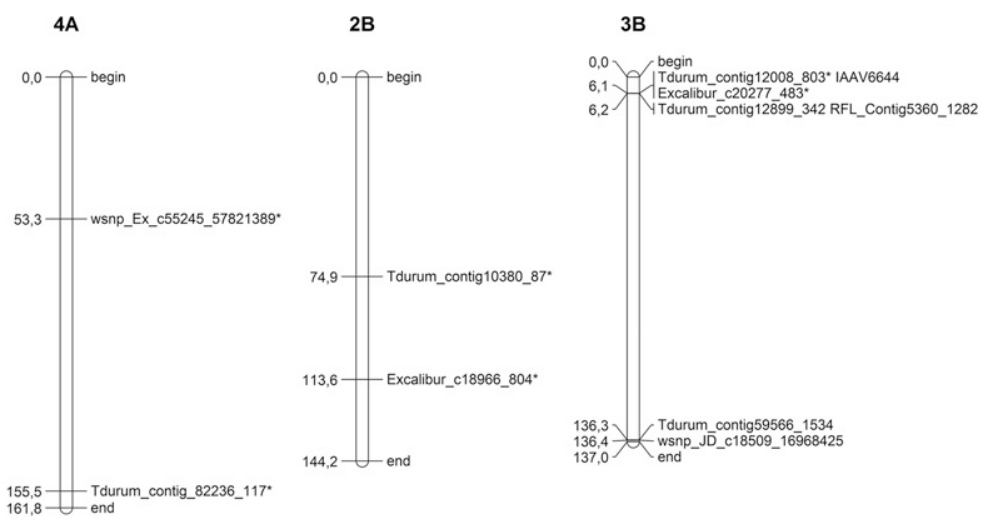
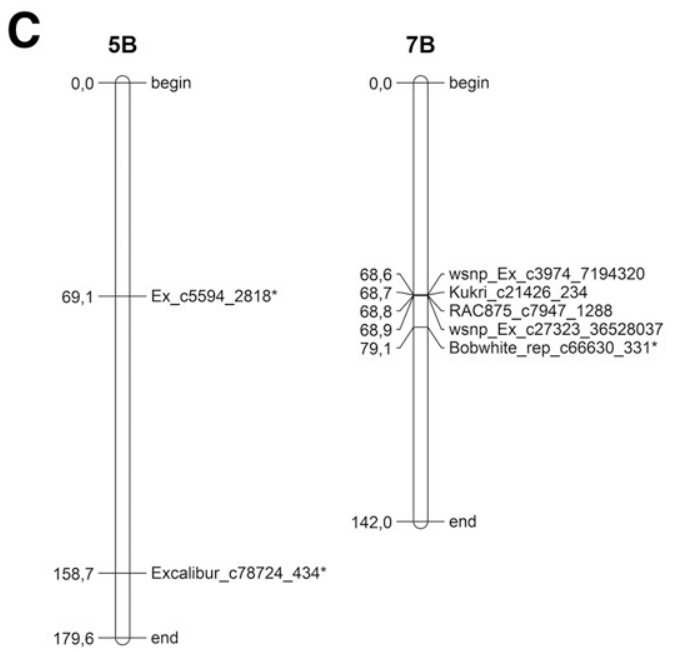

Fig. 5. The genetic map of significant single nucleotide polymorphism (SNP) markers associated with resistance to cereal cyst nematode based on International Triticeae Mapping Initiative consensus map. A, Genetic map of significant markers on chromosomes 1A, 2A, and 3A; B, genetic map of significant markers on chromosomes 4A, 2B, and 3B; and C, genetic map of significant markers on chromosomes 5 and 7B. $\mathbf{A}$ and $\mathbf{B}$ indicate wheat chromosomes, while $*$ indicates significant marker in marker trait association. Map drawn using MapChart 2.2 (Voorrips 2002). 
$10 \mathrm{cM}$. The LD heat maps for 11 significant markers were created using Haploview software (Supplementary Fig. S2A to G).

Marker-trait associations. Eleven SNP markers were significantly associated with response to $H$. filipjevi detected on chromosomes 1A, 2A, 3A, 4A, 2B, 3B, 5B, and 7B (Fig. 4). The phenotypic variation $\left(R^{2}\right)$ of individual SNPs ranged from 6.9 to $12.1 \%$ (Table 2). The total genetic variation explained by all significant markers was $43 \%$. In five cases of the 11 SNP markers (wsnp_BE443588A_Ta_2_1 (1A,97.1 cM), RAC875_c13116_943 (2A, 64.3 cM), Excalibur_c18966_804 $(2 \mathrm{~B}, 113.6 \mathrm{cM})$, wsnp_BE426418A_Ta_2_1 (3A, $20 \mathrm{cM})$, and Bobwhite_rep_c66630_331 (7B, $79.1 \mathrm{cM}))$, the alleles with higher frequency in the panel were related to resistance. In the six remaining cases the alleles with higher frequency (Tdurum_contig10380_87 (2B, $74.9 \mathrm{cM})$, Tdurum_contig1208_803 (3B, $74.9 \mathrm{cM})$, Excalibur_ c20277_483 (3B, 6.14 cM), wsnp_Ex_c55245_57821389 (4A, 53.3 cM), Tdurum_contig82236_117 (4A, $155.5 \mathrm{cM})$, and Excalibur_c78724_434 $(5 \mathrm{~B}, 158.7 \mathrm{cM})$ were related to susceptibility (Table 2$)$. The genetic maps of significant markers were generated according to Voorrips (2002) and shown in Figure 5A to C. The highest effect was recorded by the marker Tdurum_contig10380_87 $(2 \mathrm{~B}, 74.9 \mathrm{cM})$ while the lowest recorded for Excalibur_c18966_804 (2B, $113.6 \mathrm{cM})$.

Functional annotation of genes linked to SNP markers associated with $\mathrm{CCN}$ resistance. Based on the eleven significant markers, we were able to identify full ORFs associated to the QTLs (Table 3). To analyze their putative biological functions, we performed an in-silico annotation which led to the identification of intrachromosomal locations of SNPs co-localized with genes that could be involved in biotic and abiotic stress (Table 4). Further, the flanking sequences of significant SNPs were blasted against amino acid sequences from rice, sorghum, and Brachypodium (Supplementary Table S2). Eight QTLs on chromosome $1 \mathrm{AL}, 2 \mathrm{AS}, 2 \mathrm{BL}, 3 \mathrm{AL}, 4 \mathrm{AL}$, and 5BL were linked to putative genes known to be involved in plant pathogen interactions (Table 4). The QTL on chromosome 1AL linked to a putative methyl transferase 1-associated protein 1 (DMAP1) gene, which contains the SANT/ Myb domain (IPR032563) known to be involved in cell death and disease resistance. The QTL on chromosome 2AS linked to a putative a RING/FYVE/PHD-type Zinc finger gene known to regulate a superoxide-dependent signal and involved in cell death and disease resistance. The QTL on chromosome $2 \mathrm{BL}$ linked to a putative aarF domain-containing protein kinase 3 known to be involved in phosphorylating respiratory chain plastoquinoneNADPH and oxidative stress. The QTL on chromosome 3AL linked to a putative NADPH-quinone oxidoreductase subunit 0 genes, suggested to be involved in NADPH oxidation-reduction process. Another QTL on chromosome 2BL linked to a putative amino acid transporter (AAT) gene. AATs have been reported to be involved in active amino acid transport across cellular membranes in higher plants during various processes of plant growth, development, and nematode parasitism. The QTL on chromosome 4AL was associated with a putative Calmodulin-binding protein-like gene (BCL2-associated athanogene 7) known to be involved in cell proliferation, growth arrest, and cell death. The QTL on chromosome 4AS linked to a putative gene coding for a retinoblastoma-binding protein 5 known to be involved in stress response. The QTL on chromosome 7BL linked to a putative elongation factor EF-2-like protein known to be induced in response to cold stress. The QTL on chromosome $5 \mathrm{BL}$ linked to a putative gene coding for a cell division protein; however, it is not yet functionally annotated. The other two QTLs on chromosome 3BL linked to a putative RNA polymerase II-associated and Paf1 superfamily, respectively, known to be involved in early flowering.

\section{DISCUSSION}

Breeding for resistance to $\mathrm{CCN}$ in wheat was initiated in the early 1970s (Brown and Ellis 1976). Later, Kimber and Feldman (1987) identified novel resistance sources in cultivated and wild wheat relatives. However, broad-spectrum resistance to CCNs in wheat is still limited.

In general, high density SNP genotyping and genome mapping enabled the performance of association studies to identify putative QTLs linked to disease resistance (Cavanagh et al. 2013). However, false associations caused by heterogeneous populations hamper the analyses (Matthies et al. 2012; Pritchard et al. 2000). A multiple QTL model which corrected for both population structure and relatedness MLM $(\mathrm{P}+\mathrm{K})$ was used in this study and helped in separating the true functional signal from false positives. Further, a multilocus analysis with cross validation controlled the high bias of explained variance and ensures reproducible results (Bauer et al. 2009; Benjamini and Yekutieli 2005). Five QTLs identified in this study on chromosomes $1 \mathrm{AS}, 2 \mathrm{AS}, 2 \mathrm{BL}, 3 \mathrm{BL}$, and 5BL were previously linked to $H$. avenae resistance. Candidate genes underlying resistance to some of these QTLs, such as $\mathrm{Cre} 5 / \mathrm{CreX}$ on chromosome 2A, Crel on chromosome 2BL, and $\mathrm{CreY}$ on chromosome 3B were described previously (Barloy et al. 2007; Bekal et al. 1998; Jahier et al. 2001). However, genes associated to other QTLs on chromosomes $1 \mathrm{AL}$ and 5BL have not been reported before (Mulki et al. 2013; Singh et al. 2010). A recent GWAS study identified a QTL IWB66494 linked to marker Tdurum_contig10380_87 on chromosome 2BL conferring resistance to Fusarium graminearum (head blight) in spring wheat thus indicating the chromosomal region $2 \mathrm{BL}$ to be a hotspot for resistance alleles linked to multiple wheat diseases (Jansen 2015). However, at this stage, we cannot state if this QTL is linked to one or more resistance genes. The variation in chromosome and chromosomal location of significant QTLs identified different novel alleles at

TABLE 3. In silico annotation of significant markers and identified contigs ${ }^{\mathrm{a}}$

\begin{tabular}{|c|c|c|c|c|c|c|c|c|}
\hline \multirow{2}{*}{$\begin{array}{l}90 \mathrm{~K} \text { iSelect } \\
\text { SNP bead } \\
\text { chip index }\end{array}$} & \multirow[b]{2}{*}{ SNP ID } & \multirow[b]{2}{*}{ Marker name } & \multicolumn{3}{|c|}{ NCBI } & \multicolumn{3}{|c|}{ IWGSC } \\
\hline & & & E-value & Accession & Identity $\%$ & E-value & Identity $\%$ & Wheat contigs ID \\
\hline 75423 & IWA135 & wsnp_BE443588A_Ta_2_1 & $7.96 \mathrm{E}-43$ & AK332961 & 100 & $3.5 \mathrm{E}-45$ & 100 & UCW_Tu-k25_contig_5434 \\
\hline 53663 & IWB53663 & RAC875_c13116_943 & $6.98 \mathrm{E}-31$ & XM_003559795 & 92.31 & $2.37 \mathrm{E}-44$ & 99.01 & $\begin{array}{l}\text { UCW_Tu-k35_contig_173; } \\
\text { tuk21_contig_105 }\end{array}$ \\
\hline 23232 & IWB23232 & Excalibur_c18966_804 & $9.69 \mathrm{E}-42$ & AK360630 & 99.01 & $2.89 \mathrm{E}-43$ & 100 & UCW_Tu-k51_contig_8215 \\
\hline 75392 & IWA94 & wsnp_BE4̄26418A_Ta_2_1 & $1.35 \mathrm{E}-52$ & HQ389836 & 99.17 & $9.82 \mathrm{E}-19$ & 100 & UCW_Tu-k55_contig_20701 \\
\hline 5616 & IWB5616 & BobWhite_rep_c66630_331 & $6.12 \mathrm{E}-38$ & AK250157 & 96.04 & $1.49 \mathrm{E}-40$ & 100 & UCW_Tu-5_contig_768 \\
\hline 66494 & IWB66494 & Tdurum_contig10380_87 & $3.17 \mathrm{E}-16$ & XM_004963496 & 100 & $5.57 \mathrm{E}-46$ & 100 & UCW_Tu-k31_contig_15495 \\
\hline 67389 & IWB67389 & Tdurum_contig12008_803 & $9.69 \mathrm{E}-42$ & $\mathrm{AK} 375083$ & 100 & $2.37 \mathrm{E}-44$ & 100 & UCW_Tu-k21_contig_14859 \\
\hline 23457 & IWB23457 & Excalibur_c20277_483 & $2.28 \mathrm{E}-43$ & FN645450 & 100 & $5.57 \mathrm{E}-46$ & 100 & UCW_Tu-k41_contig_8030 \\
\hline 78435 & IWA4260 & wsnp_Ex_c55245_57821389 & $5.35 \mathrm{E}-83$ & AK363634 & 97.51 & $6.67 \mathrm{E}-100$ & 100 & UCW_Tu-k41_contig_14865 \\
\hline 73556 & IWB73556 & Tdurum_contig82236_117 & $1.35 \mathrm{E}-33$ & AK331337 & 95.83 & $5.57 \mathrm{E}-46$ & 100 & $\begin{array}{l}\text { UCW_Tu-k45_contig_4305; } \\
\text { tuk35_contig_3982; } \\
\text { tuk55_contig_3852 }\end{array}$ \\
\hline 28883 & IWB28883 & Excalibur_c78724_434 & $1.87 \mathrm{E}-06$ & XM_003559125 & 100 & 2.89E-43 & 100 & UCW_Tu-k35_contig_37987 \\
\hline
\end{tabular}

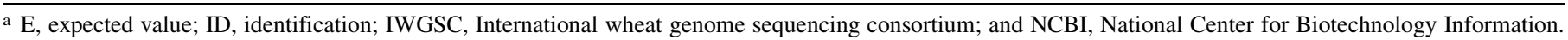


TABLE 4. Functional annotation of putative genes linked to Heterodera filipjevi resistance ${ }^{\mathrm{a}}$

\begin{tabular}{|c|c|c|c|c|c|c|c|c|}
\hline Marker & CHR & Putative gene & Allele & $\begin{array}{l}\text { Amino } \\
\text { acid } \\
\text { change }\end{array}$ & $\begin{array}{l}\text { Amino } \\
\text { acid } \\
\text { change }\end{array}$ & $\begin{array}{l}\text { Type of } \\
\text { change (I) }\end{array}$ & $\begin{array}{c}\text { Type of } \\
\text { change (II) }\end{array}$ & Putative function \\
\hline wsnp_BE443588A_Ta_2_1 & $1 \mathrm{AL}$ & $\begin{array}{l}\text { DNA methyltransferase } \\
\text { 1-associated protein } 1 \\
\text { (DMAP1) } \\
\text { (IPR032563) }\end{array}$ & $\mathrm{A} / \mathrm{C}$ & no_hit & no_hit & Transversion & & $\begin{array}{l}\text { MYB family of transcription } \\
\text { factors suggested to code in } \\
\text { controlling development, } \\
\text { secondary metabolism, } \\
\text { hormonal regulation and } \\
\text { response to biotic and } \\
\text { abiotic stress }\end{array}$ \\
\hline wsnp_BE426418A_Ta_2_1 & $3 \mathrm{AL}$ & $\begin{array}{l}\text { NAD }(\mathrm{P}) \mathrm{H} \text {-quinone } \\
\text { oxidoreductase } \\
\text { subunit O } \\
\text { (IPR020905) }\end{array}$ & $\mathrm{T} / \mathrm{C}$ & no_hit & no_hit & Transition & Synonymous & $\begin{array}{l}\text { NADH dehydrogenase } \\
\text { complex (plastoquinone) } \\
\text { assembly, oxidation } \\
\text { reduction process, } \\
\text { photosynthesis, light } \\
\text { reaction, protein } \\
\text { autophosphorylation, } \\
\text { regulation of proton } \\
\text { transport, oxidoreductase } \\
\text { activity, acting on NAD }(\mathrm{P}) \mathrm{H} \text {, } \\
\text { quinone }\end{array}$ \\
\hline Tdurum_contig12008_803 & $3 \mathrm{BL}$ & $\begin{array}{l}\text { RNA polymerase II- } \\
\text { associated, Paf } \\
\text { (IPR007133) }\end{array}$ & $\mathrm{T} / \mathrm{C}$ & $\mathrm{I}->\mathrm{T}$ & $\mathrm{I}->\mathrm{T}$ & Transition & Nonsynonymous & $\begin{array}{l}\text { Encodes a PAF1 homolog } \\
\text { which involves in the } \\
\text { control of flowering time } \\
\text { and vernalization }\end{array}$ \\
\hline Excalibur_c20277_483 & $3 \mathrm{BL}$ & $\begin{array}{l}\text { Paf1 superfamily, } \\
\text { c120260 } \\
\text { (IPR007133) }\end{array}$ & G/A & $\mathrm{R}->\mathrm{R}$ & $\mathrm{R}->\mathrm{R}$ & Transition & Synonymous & $\begin{array}{l}\text { Members of this family are } \\
\text { components of the RNA } \\
\text { polymerase II associated } \\
\text { Paf1 complex, involves in } \\
\text { the control of flowering time }\end{array}$ \\
\hline wsnp_Ex_c55245_57821389 & 4AS & $\begin{array}{l}\text { Retinoblastoma- } \\
\text { binding protein } \\
\text { 5-like/WD40-repeat- } \\
\text { containing domain } \\
\text { (IPR017986) }\end{array}$ & $\mathrm{T} / \mathrm{C}$ & $\mathrm{I}->\mathrm{V}$ & $\mathrm{I}->\mathrm{V}$ & Transition & Nonsynonymous & $\begin{array}{l}\text { Involves in tumor suppressor } \\
\text { protein RB1 gene and } \\
\text { WD40-repeat gene involves } \\
\text { in stress tolerant }\end{array}$ \\
\hline Tdurum_contig82236_117 & $4 \mathrm{AL}$ & $\begin{array}{l}\text { Calmodulin-binding } \\
\text { protein-like, BCL-2- } \\
\text { associated athanogene } \\
7 \text { (no hit) }\end{array}$ & G/A & no_hit & no_hit & Transition & & $\begin{array}{l}\text { Involves in cell proliferation to } \\
\text { growth arrest, cell death in } \\
\text { yeast, mammals and plants, } \\
\text { encodes calmodulin-binding } \\
\text { proteins response to bacterial } \\
\text { pathogens and inducers of } \\
\text { defense responses }\end{array}$ \\
\hline
\end{tabular}

a CHR, chromosome; DNA, deoxyribonucleic acid; I, isoleucine; IPR, interpro; K, lysine; MYB, myeloblastosis; N, asparagine; PAF1, polymerase-associated factor 1; R, arginine; RB1, retinoblastoma 1; RNA, ribonucleic acid; T, threonine; and V, valine. 
different loci (Table 2). Further, the moderate broad-sense heritability $(46 \%)$ suggested a potential transmission of resistance alleles to successive generations. These novel QTLs could be used for pyramiding resistance through marker-assisted backcrossing.

Genotyping analysis revealed that the polymorphic SNPs on A, $\mathrm{B}$, and $\mathrm{D}$ genomes were highly variable, indicating that recombination rates differ in the different regions of the wheat genome. Significant QTLs linked to $H$. filipjevi resistance were identified only in the A and B genome. The process of domestication might have resulted in a high number of effective recombination events in $\mathrm{A}$ and B genomes (Chao et al. 2009; Dubcovsky and Dvorak 2007). The low density SNPs in D genome could represent the historical development of hexaploid wheat (van Ginkel and Ogbonnaya 2007). Würschum et al. (2013) reported similar results with few SNPs located on the D genome in 172 European winter wheat cultivars.

Population structure and relatedness among individuals can lead to spurious associations between a candidate marker and a phenotype (Yu and Buckler 2006). Our analysis of both methods (structure (Q) and PCA (P)) yielded in very low genetic differentiation in the mapping population. We therefore conclude that the variability within the mapping panel is very low and therefore needed no further correction. As the result of structure (Q) and PCA (P) was nearly equivalent, the data were analyzed by $\mathrm{PCA}(\mathrm{P}$ and $\mathrm{P}+\mathrm{K}$ model) as most published analyses now concentrate on $\mathrm{P}$ and not $\mathrm{Q}$ to avoid the computationally demanding Q matrix in structure analysis (Price et al. 2006). In other studies two subpopulations were identified, e.g., with 96 wheat accessions and 81 diversified A. tauschii populations (Neumann et al. 2011; Sohail et al. 2012). Many other studies suggested that subpopulations existed within different mapping populations. Moreover, high marker allele frequency and low population structure justify the selection of our mapping population to perform GWAS (Myles et al. 2009).

LD is the basis of genetic association analysis discovering and mapping genes in natural populations (Wilson et al. 2004). Genetic association determines correlations between genetic variants and phenotypic differences within a population (Flint-Garcia et al. 2003). LD depends on the process of domestication, population subdivision, founding events, and selection (Rafalski and Morgante 2004). LD across wheat genome was $<3 \mathrm{cM}$, a smaller distance compared with previously reported $5 \mathrm{cM}$ (Crossa et al. 2007). Our finding supports the high LD in self-pollinating plants and could be explained by the different levels of historical recombination, effective recombination rate and recombination distance between the loci. However, it is reported that the extent of LD vary throughout the genome and introduction of new haplotypes from divergent population can increase the LD (Pritchard and Przeworski 2001). Neumann et al. (2011) reported that LD is not consistent across either whole genomes or single chromosomes. LD facilitates predicting marker density required for effective marker trait association. Dense marker coverage provides detailed insights into LD decay between two loci in close proximity and helps to identify regions influenced by a short, intense breeding history (Benson et al. 2012). The high density of SNP markers on genome $A(<3 \mathrm{cM})$ and $\mathrm{B}(2 \mathrm{cM})$ implies more accuracy in genome wide and region specific LD compared with the D genome $(>5 \mathrm{cM})$. High LD found in the A and B genome could be explained by various levels of historical recombination in the accessions and might result from favorable selection for phenotypes during breeding history by IWWIP. LD decay of $<5 \mathrm{cM}$ for 157 wheat landraces and 189 Canadian bread wheat accessions, and 5 to $10 \mathrm{cM}$ for 93 Chinese bread wheat were reported (Belzile et al. 2007).

Our analysis revealed that pyramiding two or more QTLs would enhance the performance of resistance considerably (Fig. 6). The combination of two $(1 \mathrm{AL}+7 \mathrm{BL})$, three $(1 \mathrm{AL}+3 \mathrm{AL}+7 \mathrm{BL})$, four $(1 \mathrm{AL}+2 \mathrm{AS}+2 \mathrm{BL}+3 \mathrm{AL})$, or five $(1 \mathrm{AL}+3 \mathrm{AL}+2 \mathrm{BL}+3 \mathrm{AL}+7 \mathrm{~B}) \mathrm{QTLs}$ in wheat accessions was predicted to increase the resistance response up to $74,76,85$, and $86 \%$, respectively. The three moderately resistant wheat accessions Olifants, Lantian 12, and T04/17 originating from different region possess the highest marker allele frequency (Table 5). Therefore, these lines are good candidates to be included into breeding strategies to develop durable resistance through marker-assisted backcrossing. Similarly, pyramiding resistance alleles to stripe rust has been utilized successfully in barley (Sun et al. 1997). In the same way, leaf rust resistance genes $L r 41, L r 42$, and $L r 43$ and powdery mildew resistance gene $P m 1$ and $P m 2$ were successfully pyramided in wheat (Cox et al. 1994; Liu et al. 2000). Moreover, the additive effect of combining QTLs linked to resistance against $H$. avenae on chromosomes $1 \mathrm{~B}$ and $6 \mathrm{~B}$ in Trident/Molineux DH wheat population was reported (Williams et al. 2006).

Among the 11 identified putative ORFs, the functions of two candidates are well supported statistically and biologically. Annotation of the sequences flanking the QTL on chromosome on 2BL revealed an amino acid transporter (AAT), transmembrane family protein in rice (IPR013057, Os05g0586500, NP_001056462, Table 4). AATs are integral membrane proteins that transport amino acid across cellular membranes in higher plants. An amino acid permease (AtAAP6) ortholog in A. thaliana was found to be highly expressed in syncytia induced by H. schachtii (Szakasits et al. 2009). It was also reported to be involved in supplying amino acids to feeding structures induced by Meloidogyne incognita in Arabidopsis roots and was shown to be expressed in other sink tissues (Hammes et al. 2006; Marella et al. 2013; Puthoff et al. 2003). The other candidate is linked to the QTL on chromosome 2AS. It is a putative protein

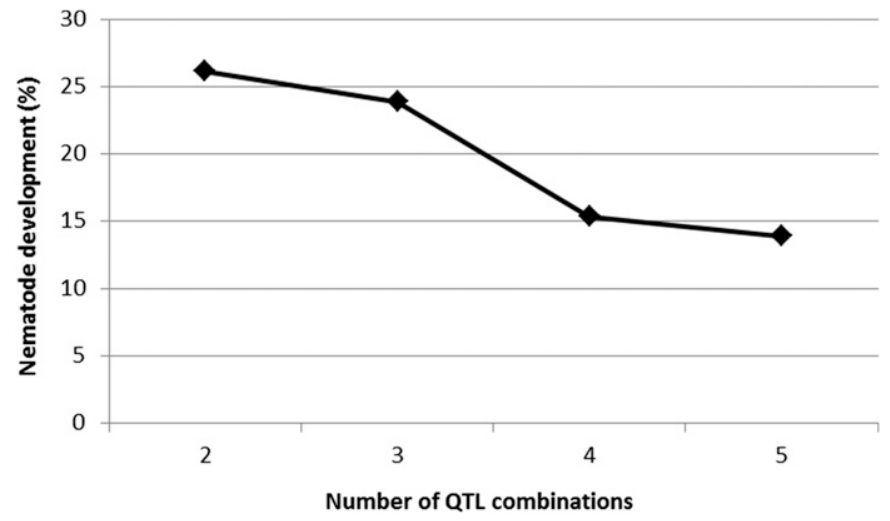

Fig. 6. Effect of quantitative trait loci (QTL) combinations on Heterodera filipjevi reduction in wheat accessions. Number of abscissa indicates the number of QTL allele combinations.

TABLE 5. Selection of wheat accessions based on significant markers frequency, host status, and origin ${ }^{\mathrm{a}}$

\begin{tabular}{|c|c|c|c|c|c|c|c|c|c|c|c|}
\hline \multirow{2}{*}{$\begin{array}{l}\text { Common } \\
\text { name }\end{array}$} & \multirow[b]{2}{*}{ Origin } & \multirow[b]{2}{*}{ Pedigree } & \multirow{2}{*}{$\begin{array}{c}\text { Accessions } \\
\text { status }\end{array}$} & \multicolumn{3}{|c|}{ Experiment 1} & \multicolumn{3}{|c|}{ Experiment 2} & \multirow{2}{*}{$\begin{array}{c}\text { Host status to } \\
\text { Heterodera filipjevi }\end{array}$} & \multirow[b]{2}{*}{ MAF $(\%)$} \\
\hline & & & & Cyst/plant & SD & SE & Cyst/plant & SD & SE & & \\
\hline Bezostaya & Russia & LUT17/SRS2 & Cultivar & 35.0 & 2.5 & 1.2 & 25.1 & 3.9 & 1.3 & HS & 83 \\
\hline T04/17 & South Africa & - & Breeding & 4.3 & 2.1 & 1.0 & 5.0 & 2.7 & 0.9 & MR & 92 \\
\hline Olifants & South Africa & - & Cultivar & 5.5 & 4.6 & 2.3 & 8.3 & 2.4 & 0.8 & MR & 75 \\
\hline Lantian 12 & China & $\begin{array}{l}\text { Qingnong } \\
\text { 4/Xiannong-4 Pedigree }\end{array}$ & Cultivar & 6.0 & 1.5 & 0.8 & 7.5 & 2.3 & 0.8 & MR & 83 \\
\hline
\end{tabular}

a HS, highly susceptible; MAF, marker allele frequency; MR, moderately resistance; SD, standard deviation; and SE, standard error. 
(LOC100822072/Brachypodium distachyon: XP_003559843) with a Zinc finger, RING/FYVE/PHD-type (IPR013083) and DDT superfamily domain (IPR018501, Table 4). Zinc finger family proteins are reported to be involved in superoxide-dependent signaling and negative regulation of cell death in A. thaliana (Dietrich et al. 1997; Kang 2013). Currently, the functions of the identified gene candidates are analyzed experimentally to study their role in the interaction with $H$. filipjevi in more detail. However, even without knowing their detailed function, the identified QTLs can already be used for novel approaches to achieve resistance against $H$. filipjevi through marker-assisted breeding.

\section{ACKNOWLEDGMENTS}

We thank International Winter Wheat Improvement Program for providing wheat accessions and the Ministry of Food Agriculture and Livestock, Republic of Turkey, and the Transitional Zone Agriculture Research Institute-Eskisehir for technical support. Special thanks to Syngenta Crop Protection AG, Basel, Switzerland for financial support of genotyping.

\section{LITERATURE CITED}

Agrama, H., Eizenga, G., and Yan, W. 2007. Association mapping of yield and its components in rice cultivars. Mol. Breed. 19:341-356.

Akhunov, E., Nicolet, C., and Dvorak, J. 2009. Single nucleotide polymorphism genotyping in polyploid wheat with the Illumina GoldenGate assay. Theor. Appl. Genet. 119:507-517.

Barloy, D., Lemoine, J., Abelard, P., Tanguy, A., Rivoal, R., and Jahier, J. 2007. Marker-assisted pyramiding of two cereal cyst nematode resistance genes from Aegilops variabilis in wheat. Mol. Breed. 20:31-40.

Barrett, J. C., Fry, B., Maller, J. D. M. J., and Daly, M. J. 2005. Haploview: Analysis and visualization of LD and haplotype maps. Bioinformatics 21: 263-265.

Bauer, A. M., Hoti, F., von Korff, M., Pillen, K., Léon, J., and Sillanpāä, M. 2009. Advanced backcross-QTL analysis in spring barley $(H$. vulgare ssp. spontaneum) comparing a REML versus a Bayesian model in multienvironmental field trials. Theor. Appl. Genet. 119:105-123.

Bekal, S., Jahier, J., and Rivoal, R. 1998. Host responses of different Triticeae to species of the cereal cyst nematode complex in relation to breeding resistant durum wheat. Fundam. Appl. Nematol. 21:359-370.

Belzile, F., Somers, D. J., Banks, T., DePauw, R., Fox, S., Clarke, J., Pozniak, C., and McCartney, C. 2007. Genome-wide linkage disequilibrium analysis in bread wheat and durum wheat. Genome 50:557-567.

Benjamini, Y., and Yekutieli, D. 2005. Quantitative trait loci analysis using the false discovery rate. Genetics 171:783-790.

Benson, J., Brown-Guedira, G., Paul Murphy, J., and Sneller, C. 2012. Population structure, linkage disequilibrium, and genetic diversity in soft winter wheat enriched for Fusarium head blight resistance. Plant Genome 5:71-80.

Bradbury, P. J., Zhang, Z., Kroon, D. E., Casstevens, T. M., Ramdoss, Y., and Buckler, E. S. 2007. TASSEL: Software for association mapping of complex traits in diverse samples. Bioinformatics 23:2633-2635.

Breseghello, F., and Sorrells, M. E. 2006. Association mapping of kernel size and milling quality in wheat (Triticum aestivum L.) cultivars. Genetics 172: 1165-1177.

Brown, J. A. M., and Ellis, S. E. 1976. Breeding for resistance to cereal cyst nematode in wheat. Euphytica 25:73-82.

Cavanagh, C. R., Chao, S., Wang, S., Huang, B. E., Stephen, S., Kiani, S., Forrest, K., Saintenac, C., Brown-Guedira, G. L., and Akhunova, A. 2013. Genome-wide comparative diversity uncovers multiple targets of selection for improvement in hexaploid wheat landraces and cultivars. Proc. Natl. Acad. Sci. 110:8057-8062.

Chao, S., Zhang, W., Akhunov, E., Sherman, J., Ma, Y., Luo, M. C., and Dubcovsky, J. 2009. Analysis of gene-derived SNP marker polymorphism in US wheat (Triticum aestivum L.) cultivars. Mol. Breed. 23:23-33.

Cockram, J., White, J., Zuluaga, D. L., Smith, D., Comadran, J., Macaulay, M., Luo, Z., Kearsey, M. J., Werner, P., and Harrap, D. 2010. Genome-wide association mapping to candidate polymorphism resolution in the unsequenced barley genome. Proc. Natl. Acad. Sci. 107:21611-21616.

Cox, T. S., Raupp, W. J., and Gill, B. S. 1994. Leaf rust-resistance genes, Lr41, Lr42 and Lr43 transferred from Triticum tauschii to common wheat. Crop Sci. 34:339-343

Crossa, J., Burgueno, J., Dreisigacker, S., Vargas, M., Herrera-Foessel, S. A., Lillemo, M., Singh, R. P., Trethowan, R., Warburton, M., and Franco, J. 2007. Association analysis of historical bread wheat germplasm using additive genetic covariance of relatives and population structure. Genetics 177:1889-1913.
Dababat, A. A., Imren, M., Erginbas-Orakci, G., Ashrafi, S., Yavuzaslanoglu, E., Toktay, H., Pariyar, S. R., Elekcioglu, H. I., Morgounov, A., and Mekete, T. 2015. The importance and management strategies of cereal cyst nematodes, Heterodera spp., in Turkey. Euphytica 202:173-188.

Dietrich, R. A., Richberg, M. H., Schmidt, R., Dean, C., and Dangl, J. L. 1997. A novel zinc finger protein is encoded by the Arabidopsis LSD1 gene and functions as a negative regulator of plant cell death. Cell 88: 685-694.

Dubcovsky, J., and Dvorak, J. 2007. Genome plasticity a key factor in the success of polyploid wheat under domestication. Science 316:1862-1866.

Earl, D. A. 2012. STRUCTURE HARVESTER: A website and program for visualizing STRUCTURE output and implementing the Evanno method. Conserv. Genet. Resour. 4:359-361.

Evanno, G., Regnaut, S., and Goudet, J. 2005. Detecting the number of clusters of individuals using the software STRUCTURE: A simulation study. Mol. Ecol. 14:2611-2620.

Flint-Garcia, S. A., Thornsberry, J. M., and Buckler, E. S., IV. 2003. Structure of linkage disequilibrium in plants. Annu. Rev. Plant Biol. 54:357-374.

Franklin, S. B., Gibson, D. J., Robertson, P. A., Pohlmann, J. T., and Fralish, J. S. 1995. Parallel analysis: A method for determining significant principal components. J. Veg. Sci. 6:99-106.

Hammes, U. Z., Nielsen, E., Honaas, L. A., Taylor, C. G., and Schachtman, D. P. 2006. AtCAT6, a sink-tissue-localized transporter for essential amino acids in Arabidopsis. Plant J. 48:414-426.

Holland, J. B., Nyquist, W. E., and Cervantes-Martínez, C. T. 2003. Estimating and interpreting heritability for plant breeding: An update. Plant Breed. Rev. 22:9-112.

Holm Nielsen, C. 1966. Untersuchungen über die Vererbung der Resistenz gegen den Getreidenematoden (Heterodera avenae) beim Weizen. Nematological 12:575-578.

Huang, S., Sirikhachornkit, A., Su, X., Faris, J., Gill, B., Haselkorn, R., and Gornicki, P. 2002. Genes encoding plastid acetyl-CoA carboxylase and 3-phosphoglycerate kinase of the Triticum/Aegilops complex and the evolutionary history of polyploid wheat. Natl. Acad. Sci. 99:8133-8138.

Hussey, R. S., and Grundler, F. M. W. 1998. Nematode parasitism of plants. Pages 213-243 in: The Physiology and Biochemistry of Free-Living and Plant-Parasitic Nematodes. R. N. Perry, ed. CABI Publishing, Wallingford, UK

Jahier, J., Abelard, P., Tanguy, M., Dedryver, F., Rivoal, R., Khatkar, S., Bariana, H., and Koebner, R. 2001. The Aegilops ventricosa segment on chromosome 2AS of the wheat cultivar 'VPM1'carries the cereal cyst nematode resistance gene Cre5. Plant Breed. 120:125-128.

Jansen, S. C. K. 2015. Genome-wide association mapping of Fusarium head blight resistance in Norwegian spring and winter wheat lines. Master thesis, Norwegian University of Life Sciences.

Kang, Z. 2013. Wheat zinc finger protein TaLSD1, a negative regulator of programmed cell death, is involved in wheat resistance against stripe rust fungus. Plant Physiol. Biochem. 30:1-9.

Kimber, G., and Feldman, M. 1987. Wild Wheat. An Introduction. Special Report, College of Agriculture, University of Missouri-Columbia.

Krasileva, K. V., Buffalo, V., Bailey, P., Pearce, S., Ayling, S., Tabbita, F., Soria, M., Wang, S., Akhunov, E., and Uauy, C. 2013. Separating homeologs by phasing in the tetraploid wheat transcriptome. Genome Biol. 14: R66.

Kump, K. L., Bradbury, P. J., Wisser, R. J., Buckler, E. S., Belcher, A. R., Oropeza-Rosas, M. A., Zwonitzer, J. C., Kresovich, S., McMullen, M. D., and Ware, D. 2011. Genome-wide association study of quantitative resistance to southern leaf blight in the maize nested association mapping population. Nat. Genet. 43:163-168.

Liu, J., Liu, D., Tao, W., Li, W., Wang, S., Chen, P., and Gao, D. 2000. Molecular marker-facilitated pyramiding of different genes for powdery mildew resistance in wheat. Plant Breed. 119:21-24.

Loureiro, I., Loureiro, C., Escorial, J. M., García Baudin, C., and Chueca, M. C. 2009. Spontaneous wheat-Aegilops biuncialis, Ae. geniculata and Ae. triuncialis amphiploid production, a potential way of gene transference. Span. J. Agric. Res. 7:614-620.

Malosetti, M., van der Linden, C. G., Vosman, B., and van Eeuwijk, F. A. 2007. A mixed-model approach to association mapping using pedigree information with an illustration of resistance to Phytophthora infestans in potato. Genetics 175:879-889.

Marella, H. H., Nielsen, E., Schachtman, D. P., and Taylor, C. G. 2013. The amino acid permeases AAP3 and AAP6 are involved in root-knot nematode parasitism of Arabidopsis. Mol. Plant-Microbe Interact. 26:44-54.

Massman, J., Cooper, B., Horsley, R., Neate, S., Dill-Macky, R., Chao, S., Dong, Y., Schwarz, P., Muehlbauer, G., and Smith, K. 2011. Genome-wide association mapping of Fusarium head blight resistance in contemporary barley breeding germplasm. Mol. Breed. 27:439-454.

Matthies, I. E., van Hintum, T., Weise, S., and Röder, M. S. 2012. Population structure revealed by different marker types (SSR or DArT) has an impact 
on the results of genome-wide association mapping in European barley cultivars. Mol. Breed. 30:951-966.

McDonald, A., Nicol, J., Luc, M., Sikora, R., and Bridge, J. 2005. Nematode parasites of cereals. Pages 131-191 in: Plant Parasitic Nematodes in Subtropical and Tropical Agriculture. CABI Publishing, Wallingford.

McIntosh, R. 1997. Breeding wheat for resistance to biotic stresses. In "Wheat: Prospects for Global Improvement". Develop. Plant Breed. 6:71-86.

Mokabli, A., Valette, S., Gauthier, J. P., and Rivoal, R. 2002. Variation in virulence of cereal cyst nematode populations from North Africa and Asia. Nematology 4:521-525.

Mulki, M. A., Jighly, A., Ye, G., Emebiri, L. C., Moody, D., Ansari, O., and Ogbonnaya, F. C. 2013. Association mapping for soilborne pathogen resistance in synthetic hexaploid wheat. Mol. Breed. 31:299-311.

Myles, S., Peiffer, J., Brown, P. J., Ersoz, E. S., Zhang, Z., Costich, D. E., and Buckler, E. S. 2009. Association mapping: Critical considerations shift from genotyping to experimental design. Plant Cell 21:2194-2202.

Neumann, K., Kobiljski, B., Denčić, S., Varshney, R., and Börner, A. 2011. Genome-wide association mapping: A case study in bread wheat (Triticum aestivum L.). Mol. Breed. 27:37-58.

Nicol, J. M., and Rivoal, R. 2008. Global knowledge and its application for the integrated control and management of nematodes on wheat. Pages 243-287 in: Integrated Management and Biocontrol of Vegetable and Grain Crops Nematodes. A. Ciancio and K. G. Mukerji, eds. Springer Academic Publishing, Dordrecht, The Netherlands.

Nilsox-Ehle, H. 1920. The resistance of some varieties of barley to H. schachtii. Hereditas 1:1-34.

Ogbonnaya, F. C., Eastwood, R. F., and Lagudah, E. 2009. Identification and utilisation of genes for cereal cyst nematode resistance (Heterodera avenae) resistance in wheat: The Australian experience. Pages 166-171 in: Cereal Cyst Nematodes: Status, Research and Outlook. I. T. Riley, J. M. Nicol, and A. A. Dababat, eds. CIMMYT, Turkey.

Pariyar, S. R., Dababat, A. A., Siddique, S., Erginbas-Orakci, G., Elashry, A., Morgounov, A., and Grundler, F. M. W. 2016. Identification and characterisation of resistance to the cereal cyst nematode Heterodera filipjevi in winter wheat. Nematology 18:377-402.

Price, A. L., Patterson, N. J., Plenge, R. M., Weinblatt, M. E., Shadick, N. A., and Reich, D. 2006. Principal components analysis corrects for stratification in genome-wide association studies. Nat. Genet. 38:904-909.

Pritchard, J. K., and Przeworski, M. 2001. Linkage disequilibrium in humans: Models and data. Am. J. Hum. Genet. 69:1-14.

Pritchard, J. K., Stephens, M., and Donnelly, P. 2000. Inference of population structure using multilocus genotype data. Genetics 155:945-959.

Puthoff, D. P., Nettleton, D., Rodermel, S. R., and Baum, T. J. 2003. Arabidopsis gene expression changes during cyst nematode parasitism revealed by statistical analyses of microarray expression profiles. Plant J. 33:911921.

Rafalski, A. 2002. Applications of single nucleotide polymorphisms in crop genetics. Curr. Opin. Plant Biol. 5:94-100.

Rafalski, A., and Morgante, M. 2004. Corn and humans: Recombination and linkage disequilibrium in two genomes of similar size. Trends Genet. 20: 103-111.

Riedelsheimer, C., Lisec, J., Czedik-Eysenberg, A., Sulpice, R., Flis, A., Grieder, C., Altmann, T., Stitt, M., Willmitzer, L., and Melchinger, A. E. 2012. Genome-wide association mapping of leaf metabolic profiles for dissecting complex traits in maize. Proc. Natl. Acad. Sci. 109:8872-8877.

Rivoal, R., Bekal, S., Valette, S., Gauthier, J. P., Fradj, M. B. H., Mokabli, A., Jahier, J., Nicol, J., and Yahyaoui, A. 2001. Variation in reproductive capacity and virulence on different genotypes and resistance genes of Triticeae, in the cereal cyst nematode species complex. Nematology 3:581-592.

Rivoal, R., and Cook, R. 1993. Nematode pests of cereals. Pages 259-303 in: Plant Parasitic Nematodes in Temperate Agriculture. K. Evans, D. L. Trudgill, and J. M. Webster, eds. CAB International, Wallingford, U.K.

Rivoal, R., and Nicol, J. 2009. Past research on the cereal cyst nematode complex and future needs. Pages 3-10 in: Cereal Cyst Nematodes: Status, Research and Outlook. I. T. Riley, J. M. Nicol, and A. A. Dababat, eds. CIMMYT, Turkey.

Scholz, U., and Sikora, R. A. 2004. Hatching behaviour and life cycle of Heterodera latipons Franklin under Syrian agro-ecological conditions. Nematology 6:245-256.

Sharp, P., Kreis, M., Shewry, P., and Gale, M. 1988. Location of $\beta$-amylase sequences in wheat and its relatives. Theor. Appl. Genet. 75:286-290.

Sikora, R. 1988. Plant parasitic nematodes of wheat and barley in temperate and temperate semiarid regions-A comparative analysis. Pages 46-68 in: Nematodes Parasitic to Cereals and Legumes in Temperate Semi-Arid
Regions. M. C. Saxena, R. A. Sikora, and J. P. Srivastava, eds. International Center for Agricultural Research in the Dry Areas (ICARDA), Aleppo, Syria.

Singh, K., Chhuneja, P., Singh, I., Sharma, S., Garg, T., Garg, M., Keller, B., and Dhaliwal, H. S. 2010. Molecular mapping of cereal cyst nematode resistance in Triticum monococcum L. and its transfer to the genetic background of cultivated wheat. Euphytica 176:213-222.

Sohail, Q., Shehzad, T., Kilian, A., Eltayeb, A. E., Tanaka, H., and Tsujimoto, H. 2012. Development of diversity array technology (DArT) markers for assessment of population structure and diversity in Aegilops tauschii. Breed. Sci. 62:38-45

Soto-Cerda, B. J., and Cloutier, S. 2012. Association mapping in plant genomes. Pages 29-54 in: Genetic Diversity in Plants. M. Caliskan, ed. INTECH Open Access Publisher.

Sun, G., Fahima, T., Korol, A., Turpeinen, T., Grama, A., Ronin, Y., and Nevo, E. 1997. Identification of molecular markers linked to the Yr15 stripe rust resistance gene of wheat originated in wild emmer wheat, Triticum dicoccoides. Theor. Appl. Genet. 95:622-628.

Szakasits, D., Heinen, P., Wieczorek, K., Hofmann, J., Wagner, F., Kreil, D. P., Sykacek, P., Grundler, F. M., and Bohlmann, H. 2009. The transcriptome of syncytia induced by the cyst nematode Heterodera schachtii in Arabidopsis roots. Plant J. 57:771-784.

Tadesse, W., Ogbonnaya, F. C., Jighly, A., Sanchez-Garcia, M., Sohail, Q., Rajaram, S., and Baum, M. 2015. Genome-wide association mapping of yield and grain quality traits in winter wheat genotypes. PLoS One 10: e0141339.

Tommasini, L., Schnurbusch, T., Fossati, D., Mascher, F., and Keller, B. 2007. Association mapping of Stagonospora nodorum blotch resistance in modern European winter wheat varieties. Theor. Appl. Genet. 115:697-708.

van Ginkel, M., and Ogbonnaya, F. 2007. Novel genetic diversity from synthetic wheats in breeding cultivars for changing production conditions. Field Crops Res. 104:86-94.

van Slageren, M. 1994. Wild wheats: A monograph of Aegilops L. and Ambylopyrum (Jaub and Spach) Eig (Poaceae). Wageningen Agricultural University. The Netherlands and Int. Cent. for Agric. Res. Dry Areas, Aleppo, Syria.

Voorrips, R. E. 2002. MapChart: Software for the graphical presentation of linkage maps and QTLs. J. Hered. 93:77-78.

Wang, S., Wong, D., Forrest, K., Allen, A., Chao, S., Huang, B. E., Maccaferri, M., Salvi, S., Milner, S. G., and Cattivelli, L. 2014. Characterization of polyploid wheat genomic diversity using a high-density 90,000 single nucleotide polymorphism array. Plant Biotechnol. J. 12:787-796.

Wang, Z., Taramino, G., Yang, D., Liu, G., Tingey, S., Miao, G., and Wang, G. 2001. Rice ESTs with disease-resistance gene-or defense-response genelike sequences mapped to regions containing major resistance genes or QTLs. Mol. Genet. Genomics 265:302-310.

William, M., Singh, R., Huerta-Espino, J., Islas, S. O., and Hoisington, D. 2003. Molecular marker mapping of leaf rust resistance gene Lr46 and its association with stripe rust resistance gene Yr29 in wheat. Phytopathology 93:153-159.

Williams, K. J., Willsmore, K. L., Olson, S., Matic, M., and Kuchel, H. 2006. Mapping of a novel QTL for resistance to cereal cyst nematode in wheat. Theor. Appl. Genet. 112:1480-1486.

Williamson, V. M., and Kumar, A. 2006. Nematode resistance in plants: the battle underground. Trends Genet. 22:396-403.

Wilson, L. M., Whitt, S. R., Ibáñez, A. M., Rocheford, T. R., Goodman, M. M., and Buckler, E. S. 2004. Dissection of maize kernel composition and starch production by candidate gene association. Plant Cell 16:2719-2733.

Würschum, T. 2012. Mapping QTL for agronomic traits in breeding populations. Theor. Appl. Genet. 125:201-210.

Würschum, T., Langer, S. M., Longin, C. F. H., Korzun, V., Akhunov, E., Ebmeyer, E., Schachschneider, R., Schacht, J., Kazman, E., and Reif, J. C. 2013. Population structure, genetic diversity and linkage disequilibrium in elite winter wheat assessed with SNP and SSR markers. Theor. Appl. Genet. 126:1477-1486.

Xu, Y., and Crouch, J. H. 2008. Marker-assisted selection in plant breeding: from publications to practice. Crop Sci. 48:391-407.

Yao, J., Wang, L., Liu, L., Zhao, C., and Zheng, Y. 2009. Association mapping of agronomic traits on chromosome 2A of wheat. Genetica 137:67-75.

Yu, J., and Buckler, E. S. 2006. Genetic association mapping and genome organization of maize. Curr. Opin. Biotechnol. 17:155-160.

Zou, J., Pan, X., Chen, Z., Xu, J., Lu, J., Zhai, W., and Zhu, L. 2000. Mapping quantitative trait loci controlling sheath blight resistance in two rice cultivars (Oryza sativa L.). Theor. Appl. Genet. 101:569-573. 